ARTICLE HISTORY: Received: May 18, 2021 Accepted: July 11, 2021 Published: July 19, 2021

\title{
ISRAEL: TRANSPORT COSTS AND CUSTOMS DUTY - IS ON YOU THE INCREASE IN CUSTOMS VALUE IN ISRAEL, DUE TO THE INCREASE IN TRANSPORT PRICES - THE PROBLEM, AND THE WAY TO THE SOLUTION
}

Adv. Omer Wagner ${ }^{I}$

\begin{abstract}
This article discusses transport costs and customs duties, namely the problems and solutions to the increase in customs value in Israel due to the increase in transport prices
\end{abstract}

Keywords: Israel, transport costs, customs duties, customs value.

In the past year, sea freight prices have risen sharply, an increase that has not been remembered for many years.

Thus, according to various publications, about a year ago, renting a container for sea transportation from China to Israel, costed about $2,000 \$$, and today, the same transportation costs about $15,000 \$$.

According to the publications, the reasons for this significant increase are due, among other things, to the COVID19 crisis, global shortages of ships, declining competition in the field, and containers of contagious demand. In addition, there is a "Made of Israel" reason, since due to the congestion at ports in Israel, there are ships that prefer not to dock in Israel, and then the number of ships that can dock in Israel is even smaller ${ }^{2}$.

Apart from the increase in transportation costs, which is expected to lead to a wave of price increases in the sale of products in Israel, there is another parameter that is slightly pushed to the margins, and that is the increase in the value of goods for customs purposes, due to rising transportation prices. This increase in prices leads to further collection of customs duties, purchase tax and import taxes, due to the increase in value.

As I will present in this review, in my opinion - the Israeli law already allows the state to facilitate importers at this point - and similar and other facilitations have been made in the past. All that is required is the flexibility and activation of goodwill on the part of the state, when interpreting the law.

How is the value of the goods determined for customs and import taxes in the State of Israel?

Section 132 (a) of the Israeli Customs Ordinance [new version], stipulates that the value of the transaction is: "the price paid or to be paid for the goods, when sold for export to Israel ... plus the expenses and amounts specified in section 133."...

Section 133 of the Ordinance, which refers to "assists" to the transaction price for customs purposes, enumerates a large number of examples, one of which, relevant to its case, relates to transportation costs, and subscribes to section 133 (a)(5)(a) of the Ordinance, which relates to:

"The following costs involved in bringing the goods to the port of import or place of import - (a) The cost of transporting the goods to the port of import or place of import, excluding such costs incurred due to special circumstances beyond the control of the importer and the Director determining not to include them in the transaction; This includes types of goods, types of transportation and other services".

And subsection 133 (a)(5)(c) - "The cost of insurance."

That is, if we try to compare this to the terms of sale of Incoterms, it seems that the State of Israel has determined that the customs duty will be levied on the value of CIF (cost, insurance \& freight), i.e. the value of the goods including transport and insurance.

How is the value determined for customs, worldwide?

It should be noted that there is no uniform rule in this matter.

Most countries in the world are members of the World Trade Organization (WTO) and the World Customs Organization (WCO), and by virtue of their membership, have signed an international agreement on the valuation of goods for customs purposes ${ }^{3}$.

The agreement sets out a number of rules regarding the way goods are valued for customs purposes, but it does not stipulate any binding rules regarding transportation.

${ }^{1}$ The author is employed in the indirect taxation department at PWC Israel, Kesselman\&Kesselman, and is an attorney specializing in customs law, purchase tax, indirect taxation, import, export, regulation, trade levies, international trade; What is said in the article reflects the opinion of the author only, and should not be considered as giving a legal opinion.

${ }^{2}$ https://www.ynet.co.il/economy/article/rJrNcwAcd

3 Customs Valuation Agreement (Implementation of Article VII of the GATT) https://www.wto.org/english/res_e/publications_e/ai17_e/cusval_e.htm 
There are countries where the value on which the customs duty is imposed is FOB (free on board), that is, without the sea transport, and there are countries where the value on which the customs duty is imposed is CIF, including the transport.

For comparison, in the United States, a different method is used than in the State of Israel, and in the United States, customs duties are imposed on the value without sea transportation. Thus, the corresponding section in American law to section 132 of the Customs Ordinance in Israel, which deals with the "transaction price", states in US law that ${ }^{4}$ :

"The transaction value of imported merchandise is the price actually paid or payable for the merchandise when sold for exportation to the United States"..

As for transportation costs, American law goes on to state that the value to customs will not include them:

(3)"The transaction value of imported merchandise does not include any of the following, if identified separately from the price actually paid or payable and from any cost or other item referred to in paragraph (1): (A) Any reasonable cost or charge that is incurred for-

(ii) the transportation of the merchandise after such importation" .

Hence, it seems that in the US, an increase in freight rates does not increase the value of the goods for customs purposes.

In Israel, on the other hand, any increase in freight also embodies the increase in value to customs, and, accordingly, increases the customs burden imposed on the importer.

That is, if we assume for the purpose of the example, that a spare part for a car is subject to a purchase tax of about $20 \%$ of the value to customs, then any increase of $1,000 \$$ in transportation prices embodies an additional purchase tax of $200 \$$ by the State of Israel. Since this is an indirect tax, it will, by its very nature, ultimately be passed on to the entire public, in the form of rising prices.

How has the State of Israel dealt with such similar situations in the past?

Price increases in the field of transportation can be caused by a wide variety of reasons. Among other things, wars, closures, sanctions, strikes, and a host of other reasons may increase transportation prices.

In this regard, section 133 (a)(5) of the Customs Ordinance stipulates that in exceptional situations, the director of customs may not include in the value of customs certain transportation costs. The law calls them:

"such costs incurred due to special circumstances over which the importer has no control and the manager has determined that they should not be included in the value of the transaction;"

These are, in fact, transportation costs that are a kind of "force majeure" that the importer did not have the ability to prevent.

It should be noted that the Customs Authority exercised this authority, and sometimes exempted transport costs, due to certain circumstances

On April 24 ${ }^{\text {th }}, 2006$, Customs ruled that transportation costs due to the Second Lebanon War would not be included in the customs entry:

"In accordance with my authority under section 133 (a) (5) (a) of the Customs Ordinance, I stipulate that war levies and additional transportation costs incurred by importers due to the security incidents in the north of the country, should not be included in the value of the transaction for the purpose of calculating the import taxes. It is clarified that these are additional transportation, unloading and loading costs listed in the cargo account that were caused due to the security incidents".

On June $6^{\text {th }}, 2008$, the Customs ruled that the container demurrage fee beyond the agreed, will not be included in the customs entry:

"..The demurrage fee in the importing country, which is charged for the use of the container beyond the agreed period between the ship's agent and the importer, will not be included for import taxes".

On September $7^{\text {th }}, 2008$, Customs exempted certain transportation costs in respect of strikes from being included in the customs entry, stating:

"In accordance with my authority under section 133 (a) (5) (a) of the Customs Ordinance, I provide that additional transportation costs incurred by importers due to sanctions in the ports of Israel, will not be considered for the transaction value for the purpose of calculating import taxes. It is clarified that these are additional transportation, unloading and loading costs listed in the cargo account, which were caused due to the sanctions and the importer has no control over them. The importer must prove the existence of such additional costs".

Can the state of Israel also help in the current situation?

According to the publications, the Israeli Chamber of Commerce recently appealed to the director of customs to exercise his authority, and set a type of ceiling on which customs would be imposed, even if in practice transport costs are currently more expensive, and this application was denied by customs ${ }^{5}$.

\footnotetext{
${ }^{4}$ Tariff act of 1930, 19. U.S.C. $\$ 1401 \mathrm{a}(\mathrm{b})(1),(3)$

5 https://www.chamber.org.il/foreigntrade/1109/1111/116962/
} 
Customs stated that this was a request to reduce the actual cost of transport - something that is not possible, noting that when it came to a request to reduce additions to the value of transport, such as vessels that declared "end of journey" in Cyprus and refrained from entering Israel due to the COVID-19 crisis. Customs further stated that it has not been proven that the increase in transportation prices is due to the COVID-19 or an unforeseen situation, therefore no reduction can be made under the exception in section 133 (a)(5) of the Customs Ordinance, and even claimed that if the State of Israel accepts the claim, this will be a breach of the International Agreement on the Valuation of Goods

**So the question is basically: can in the present case, transportation costs raised by tens or hundreds of percent, due to global COVID-19 crisis, shortage of ships, heavy loads in Israeli ports, shortage of containers, constitute "special circumstances beyond the importer's control"?

** With all due respect, in my opinion, this point deserves further thought and discussion

In my opinion, if the Second Lebanon War is an unforeseen event over which the importer has no control, as well as sanctions or strikes, then the interpretation of the law could be a little more flexible, and determined that a global COVID-19 crisis, shortage of ships, containers, To be considered as special circumstances over which the importer has no control.

In this regard, I would like to bring to the readers' attention a ruling given in the Israeli court on another issue, but it was stated in it, in relation to the Corona crisis, that it is certainly an unexpected event ${ }^{6}$ :

"It is hard to believe that the reasonable person could or should have expected the full far- reaching consequences of the Corona epidemic, including on the economy and commercial life, in Israel and around the world. We are dealing with an unparalleled epidemic which has no precedent in the last hundred years (at least since the Spanish Flu epidemic which caused many deaths around the world between the years 1918 - 1920 )". valuation.

**These right things, can and should be applied, in my opinion - also in the field of international trade and customs

Does anyone in the Customs Authority believe that the simple, lone importer, even if it is a wealthy business company, has any control over the changes in world freight rates? Could any importer have anticipated the corona crisis?

**In the end, if my opinion will be adopted, the legal solution, is to relieve the importers of the customs duty imposed on the transport that has become more expensive - it already exists. The "invention of the wheel" is not required here.

Now only goodwill is required, and little flexibility in interpreting the law.

${ }^{6}$ Hdlt (Tel-Aviv) 26076-02-20 Adv. Israel Bachar vs. comfortability systems (2007) Ltd. (July $\left.8^{\text {th }}, 2020\right)$; 